\title{
Presence of Bucephalus polymorphus, Echinoparyphium recurvatum and Aspidogaster limacoides (Platodes, Trematoda) in the visceral mass of Dreissena polymorpha (Mollusca, Bivalvia)
}

\author{
J. LAJTNER \\ Department of Zoology, Division of Biology, Faculty of Science, University of Zagreb, Rooseveltov trg 6 , \\ HR-10000 Zagreb, Croatia, E-mail: jlajtn@zg.biol.pmf.hr
}

\begin{abstract}
Summary
The invasive bivalve species Dreissena polymorpha (Pallas, 1771) has become one of the most dominant species in many lakes and rivers of Europe and North America. The aim of this study was to investigate changes in the structure of the visceral mass depending on the reproductive cycle and to determine the presence and effects of trematodes on the zebra mussel. Mussels were collected from the Dubrava dam reservoir during eight sampling sessions from January to December 2000. For histological analysis, 80 mussels were placed in Bouin's fixative for 24 hours, embedded in paraffin and cut with a microtome into $10 \mu \mathrm{m}$ slices. The sections were then stained with haematoxylin and eosin. Analysis of non-infected bivalves indicated that gametogenesis started in late summer, while spawning began in April. In July, the majority of mussels were in the post-spawning stage. Two mussels were infected with Bucephalus polymorphus, one with Echinoparyphium recurvatum and one with Aspidogaster limacoides. Obtained results demonstrated that the gonads were the most affected organs in mussels infected by $B$. polymorphus, the infection by $A$. limacoides resulted in a significant reduction of all investigated organs, while the infection by $E$. recurvatum had no visible pathogenic changes in the structure of visceral mass.
\end{abstract}

Keywords: zebra mussel; Dreissena polymorpha; trematodes; Bucephalus polymorphus Echinoparyphium recurvatum; Aspidogaster limacoides

\section{Introduction}

The invasive bivalve species zebra mussel (Dreissena polymorpha, Pallas, 1771) is a Ponto-Caspian species that began to spread throughout the watercourses of Europe in the early 19th century (Morton, 1969; Stanczykowska, 1977), and its spread continues today. This species began to colonize Croatian waterbodies only in the 1980 s, when it began to spread from the Danube upstream into the Drava River. In the early $1990 \mathrm{~s}, D$. polymorpha was first found in the Dubrava dam reservoir lake (Erben et al., 2000). In the meantime, it has spread upstream to the Čakovec dam reservoir lake and the Varaždin dam reservoir lake, and is currently present throughout the entire course of the Drava River flowing through Croatia (Lajtner et al. 2004; Erben et al., 2009). In 1985, this species was reported in the Great Lakes of North America (Hebert et al., 1989) and quickly spread to new areas. Wherever this species appears, it quickly becomes very abundant within freshwater ecosystems and has thus resulted in significant ecological and economic impacts.

This species has also been a vector for the spread of other species, especially endosymbionts (Karatayev et al., 2000; Burlakova et al., 2000). Molloy et al. (1997) listed 34 taxa of endosymbionts, including ciliates, trematodes, nematodes, chironomids, oligochaetes, mites and leeches associated with Dreissena. Seven genera of trematodes have been reported as parasites of Dreissena spp.: Bucephalus (Digenea: Bucephalidae), Phyllodistomum (Digenea: Gorgoderidae), Echinoparyphium and Echinostoma (Digenea: Echinostomatidae), Sanguinicola (Digenea: Sanguinicolidae), Leucochloridiomorpha (Digenea: Brachylaemidae) and Aspidogaster (Aspidogastrea: Aspidogastridae) (Conn \& Conn, 1995; Molloy et al., 1997; Laruelle et al., 2002; Peribanez et al., 2006, Lajtner et al., 2008). In its life cycle, D. polymorpha can be the first intermediate host (e.g. for Bucephalus polymorphus and Phyllodistomum spp.), second intermediate host (e.g. for Echinoparyphium recurvatum) or sole host (e.g. for Aspidogaster spp.).

The aim of the present paper was to investigate changes in the structure of visceral mass depending on reproductive cycle and study the presence and effects of the trematodes Bucephalus polymorphus Baer, 1827, Echinoparyphium recurvatum (Linstow, 1873) and Aspidogaster limacoides Diesing, 1834 on the zebra mussel, D. polymorpha. 


\section{Material and methods}

\section{Study site and sampling}

Bivalve sampling was conducted every 35 to 40 days in the period from January to December of 2000 . The station $\left(46^{\circ} 19^{\prime} \mathrm{N}, 16^{\circ} 41^{\prime} \mathrm{E}\right)$ is within a dam reservoir lake, approximately $4 \mathrm{~km}$ upstream of the dam, at a depth of $5 \mathrm{~m}$ and with a concrete substrate. The bivalves were collected by divers. During collection, special care was taken not to damage the bivalves, as the byssus threads were firmly attached to the substrate. The bivalves were transported to the laboratory in $20 \mathrm{~L}$ containers containing lake or river water.The following physical, chemical and microbial parameters were recorded: water temperature, ${ }^{\circ} \mathrm{C}$ (range $5.80-21.80$ ), $\mathrm{pH}$ (range $7.63-8.37$ ), dissolved oxygen, $\mathrm{mg} / \mathrm{l}$ (range $5.30-11.54$ ), calcium, $\mathrm{mg} / \mathrm{l}$ (range 33.60 48.05), total hardness, mg $\mathrm{CaCO}_{3} / \mathrm{l}$ (range 120.00 164.00), alkalinity, $\mathrm{ml} 0.1 \mathrm{~N} \mathrm{HCl} / 1-\mathrm{m}$ (range $2.30-2.70$ $2.00-2.60$ ), chlorophyll $a, \mathrm{mg} / \mathrm{m}^{3}$ (range $0.10-3.34$ ).

\section{Histological procedures}

Upon arrival at the laboratory, animals were placed in two flow-through aquaria with a volume of 100 litres and containing dechlorinated water. After 24 hours, they were subjected to further analysis, and during this time they were not fed. Animals from the aquaria were first placed on ice for one hour before tissue samples were taken for histological analysis. Ten animals were sampled each month, for a total of 80 bivalves during the year.

After morphometric measurements of the bivalves (length, width, height), the bivalves were carefully opened. Histological samples were fixed in Bouin's stain for 24 hours, and then rinsed in $75 \%$ ethanol for the next 24 hours. After that, tissue samples were dehydrated through a series of alcohols of increasing concentrations. Tissue was held in each alcohol concentration for one hour, and upon completion of the series, was transferred to chloroform and left overnight. The following day, the tissue was embedded in Paraplast Plus (melting point $56{ }^{\circ} \mathrm{C}$ ) and special care was taken regarding tissue position, to ensure that all samples would be cut transversally in the same way. Slices were made on a Reichert microtome to a thickness of $10 \mu \mathrm{m}$, and were then stained using standard methods for histomorphological analyses (haematoxylin and eosin staining) (Romeis, 1968). Preparations were examined on a NIKON Eclipse E600 microscope, with total magnification of 100, 200 and 400x. The state of the gonads was determined by examining the histological preparations.

The quantification of the size of the gonads and digestive glands is problematic in bivalves, as it is not possible to separate them from the remaining organs in the gut. Therefore, the special quantitative and qualitative analysis according to Borcherding (1991) was applied in measuring volume. Ten sections per animal were recorded using an OLYMPUS C 4040 digital camera attached to an OLYMPUS SZ 40 dissecting scope, ensuring that the entire transversal section was included in the field of vision. These photographs were then calibrated and computer analysed. The areas of the whole visceral mass, gonads, digestive gland and trematodes were measured using an image analysing system (LUCIA G 4.81). In order to calculate volumes, the mean tissue areas of each mussel were multiplied by the corresponding length of the visceral mass. In addition, the indices of gonad, digestive gland and other tissues of the visceral mass and trematodes were calculated as the percentage of tissue to the visceral mass volume (Borcherding, 1991).

\section{Results}

The analysis of histological sections indicated that 4 of the 80 bivalves examined were infected by trematodes $(5 \%$ infection prevalence). Two bivalves were infected by sporocysts of the trematode Bucephalus polymorphus, one of which was a male and the second a hermaphrodite. An adult trematode Aspidogaster limacoides was found in a male, and metacercaria of the species Echinoparyphium recurvatum were found in a second male.

Table 1. Comparison between mean values $( \pm$ SD) of uninfected mussels Dreissena polymorpha and mussels infected with Bucephalus polymorphus

\begin{tabular}{|c|c|c|c|c|}
\hline & \multicolumn{2}{|c|}{ July } & \multicolumn{2}{|c|}{ August } \\
\hline & $\begin{array}{c}\text { Mussels } \\
\text { without } \\
\text { trematodes } \\
(n=9)\end{array}$ & $\begin{array}{c}\text { Mussel } \\
\text { infected with } \\
\text { B. polymorphus }\end{array}$ & $\begin{array}{l}\text { Mussels } \\
\text { without trematodes } \\
\qquad(\mathrm{n}=9)\end{array}$ & $\begin{array}{c}\text { Mussel } \\
\text { infected with } \\
\text { B. polymorphus }\end{array}$ \\
\hline Length of visceral mass (mm) & $9.6 \pm 0.6$ & 14.5 & $9.1 \pm 1.0$ & 9.7 \\
\hline Visceral mass volume $\left(\mathrm{mm}^{3}\right)$ & $73.6 \pm 13.2$ & 195.3 & $65.1 \pm 18.7$ & 78.5 \\
\hline Gonad volume $\left(\mathrm{mm}^{3}\right)$ & $42.4 \pm 8.9$ & 12.7 & $30.2 \pm 11.7$ & 2.0 \\
\hline Digestive gland volume $\left(\mathrm{mm}^{3}\right)$ & $13.0 \pm 2.8$ & 21.1 & $15.9 \pm 5.3$ & 8.3 \\
\hline $\begin{array}{l}\text { Volume of other tissues } \\
\text { of visceral mass }\left(\mathrm{mm}^{3}\right)\end{array}$ & $18.1 \pm 2.8$ & 22.3 & $18.9 \pm 2.7$ & 20.9 \\
\hline Volume of trematodes & 0 & 139.2 & 0 & 47.3 \\
\hline
\end{tabular}




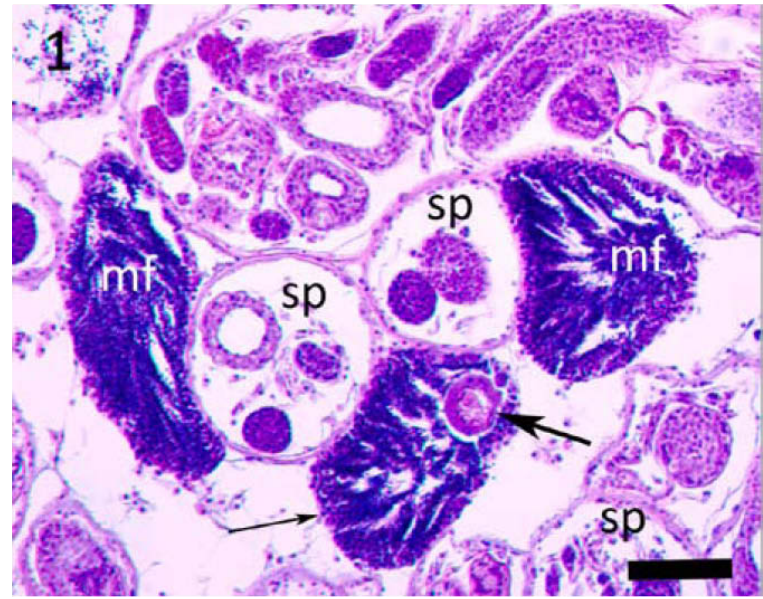

Fig. 1. Gonads of Dreissena polymorpha filled with sporocyst branches containing cercariae of Bucephalus polymorphus: $\mathrm{mf}$ - male follicle; sp - sporocyst; thin arrow - hermaphroditic follicle; thick arrow - ovum. Bar $=100 \mu \mathrm{m}$.

Reproductive cycle of the bivalves

Histological analysis of non-infected bivalves indicated that in January, the majority of analysed animals were in the stage of gametogenesis, and only a small number were still in the dormant stage. In March, the majority of animals were in the gametogenesis stage, however, the first individuals were found to be in the pre-spawning stage. The spawning process began in April, as confirmed by the finding of individuals in the post-spawning stage, though the majority of individuals in that month were still in the pre-spawning stage. In June, the majority of bivalves had already spawned, and only a small portion was in the prespawning stage. The gonad dormancy stage was already observed in July, and in August, the first individuals beginning the new gametogenesis stage were detected. During autumn and in early winter, the share of animals in the gametogenesis stage increased gradually, while the share of those in dormancy decreased.

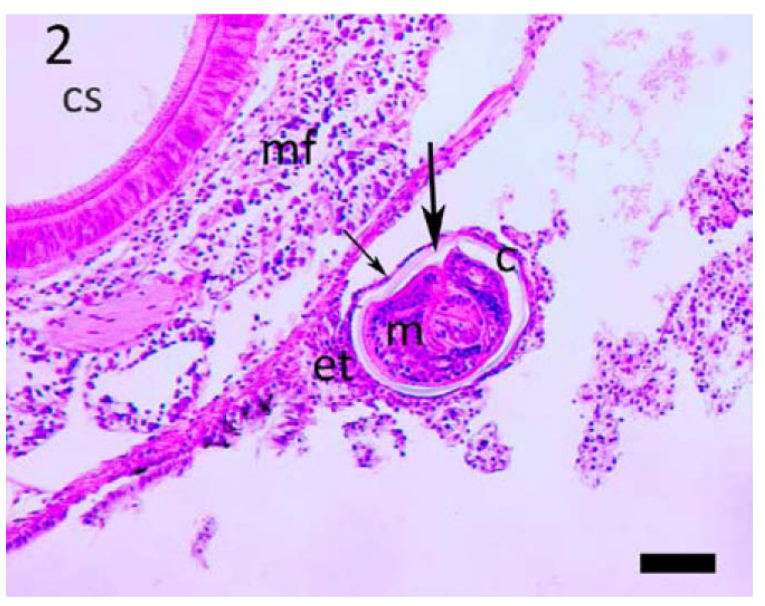

Fig. 2. Metacercaria of Echinoparyphium recurvatum in the epithelium of visceral mass of D. polymorpha; c - cyst; cs - cristalline style sac; et - epithelium of visceral mass; $\mathrm{m}$ - metacercaria; $\mathrm{mf}$ - male follicle; thin arrow - encapsulation; thick arrow - cyst wall. Bar $=80 \mu \mathrm{m}$.
Bucephalus polymorphus (Digenea: Bucephalidae)

The species $B$. polymorphus is determined according to the shape of its sporocysts, its position within the bivalve and according to the morphological properties of the cercariae. Bivalves infected with the trematode $B$. polymorphus were found in July and August.

In the hermaphrodite sampled in July, the spawning process was already complete, however, some follicles still contained mature sperm and eggs (Fig. 1). The majority of bivalves at that station had already completed spawning, some were already in the dormant phase, while there were some in the same stage as these individuals. In relation to visceral mass volume, the gonad volume of the bivalve infected by the trematodes was $6.5 \%$, while the trematode volume was $71.3 \%$, indicating a strong infection (Table 1). In analysing the gonad volume, $6.2 \mathrm{~mm}^{3}$ (49\%) was made up of male (spermatogenic) follicles, $5.4 \mathrm{~mm}^{3}$ (42.7\%) of female (oogenic) follicles and $1.1 \mathrm{~mm}^{3}(8.3 \%)$ of hermaphroditic follicles.

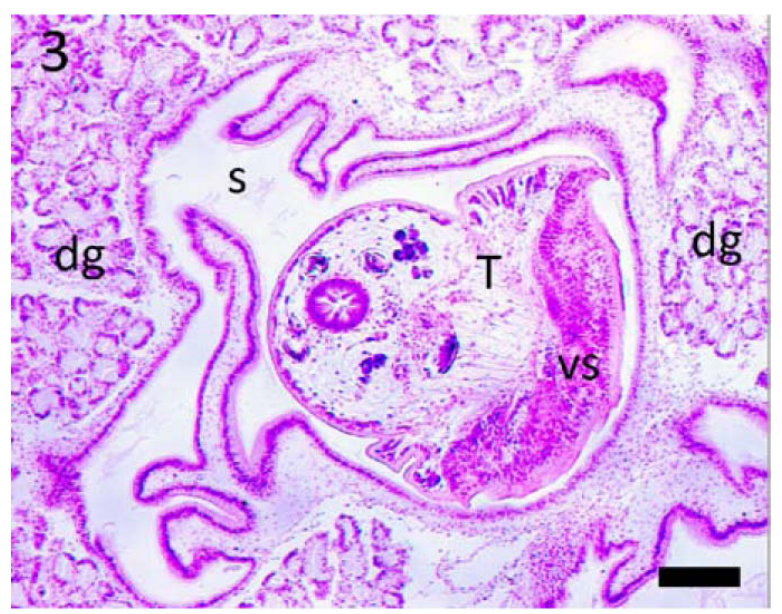

Fig. 3. Aspidogaster limacoides in the stomach of Dreissena polymorpha: dg - digestive gland, s - stomach; $\mathrm{T}$ - trematoda, vs - ventral sucker disc. $\mathrm{Bar}=100 \mu \mathrm{m}$.

The male sampled in August was in the resting stage as were most of the healthy bivalves. However, one part had already begun the process of new gametogenesis. In relation to visceral mass volume, the gonad volume of infected mussel was $2.5 \%$, while the trematode volume was $60 \%$ (Table 1 ). Sporocyst had numerous branches that were visible in the preparations as irregularly shaped tubules in which the cercariae were developing. It was also observed that all cercariae were not in the same stage of development, and sporocysts contained both young and mature cercariae. Trematodes were also found in other parts of the visceral mass and in the gills, mantle, pericardial cavity and kidney. However, in both analysed bivalves, infection was most pronounced in the gonads.

In comparison with the healthy bivalves, the gonadal index of infected bivalves was significantly lower, unlike the index of the digestive glands and index of other tissues in the visceral mass, which confirms that the gonads are the primary organ of infection by B. polymorphus (Fig. 4). 
Table 2. Comparison between mean values $( \pm \mathrm{SD})$ of uninfected mussels Dreissena polymorpha and mussels infected with Echinoparyphium recurvatum and Aspidogaster limacoides. Mussels were collected in October.

\begin{tabular}{lccc}
\hline & $\begin{array}{c}\text { Mussels } \\
\text { without trematodes } \\
(\mathrm{n}=8)\end{array}$ & $\begin{array}{c}\text { Mussel } \\
\text { infected with } \\
\text { E. recurvatum }\end{array}$ & $\begin{array}{c}\text { Mussel } \\
\text { infected with } \\
\text { A. limacoides }\end{array}$ \\
\hline Length of visceral mass $(\mathrm{mm})$ & $9.2 \pm 1.51$ & 10.1 & 7.7 \\
Visceral mass volume $\left(\mathrm{mm}^{3}\right)$ & $58.1 \pm 18.9$ & 80.0 & 37.5 \\
Gonad volume $\left(\mathrm{mm}^{3}\right)$ & $29.5 \pm 10.6$ & 46.7 & 19.5 \\
Digestive gland volume $\left(\mathrm{mm}^{3}\right)$ & $12.0 \pm 3.8$ & 15.6 & 7.1 \\
Volume of other tissues & $16.6 \pm 4.9$ & 17.7 & 10.2 \\
of visceral mass $\left(\mathrm{mm}^{3}\right)$ & 0 & 0.004 & 0.7 \\
Volume of trematodes $\left(\mathrm{mm}^{3}\right)$ & & & \\
\hline
\end{tabular}

Echinoparyphium recurvatum (Digenea: Echinostomatidae) Two cysts with metacercariae of the species E. recurvatum were found in a male sampled in October. The bivalve gonads were dormant. One cyst with a metacercaria was found in the connective tissue, between the gonads and digestive glands, and the second in the outer epithelium of the visceral mass (Fig. 2). The cysts were round with double cell walls and surrounded by a thin layer of cells of the bivalve connective tissue. In comparison with the healthy bivalves, no pathogenic tissue changes were observed in infected individuals.

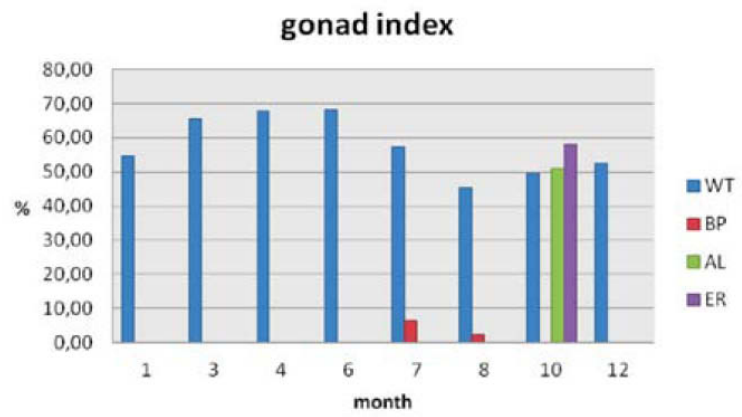

volume shows that this individual is larger in comparison with other bivalves sampled during October at the same station. This refers, in particular, to the length and volume of the visceral mass and the gonad volume (Table 2).

The gonadal index of the infected individual was higher than the mean value of the gonadal index of uninfected bivalves, while the indices of the digestive glands and remaining tissues of the visceral mass were slightly lower than the mean values of the uninfected individuals (Fig. 4).
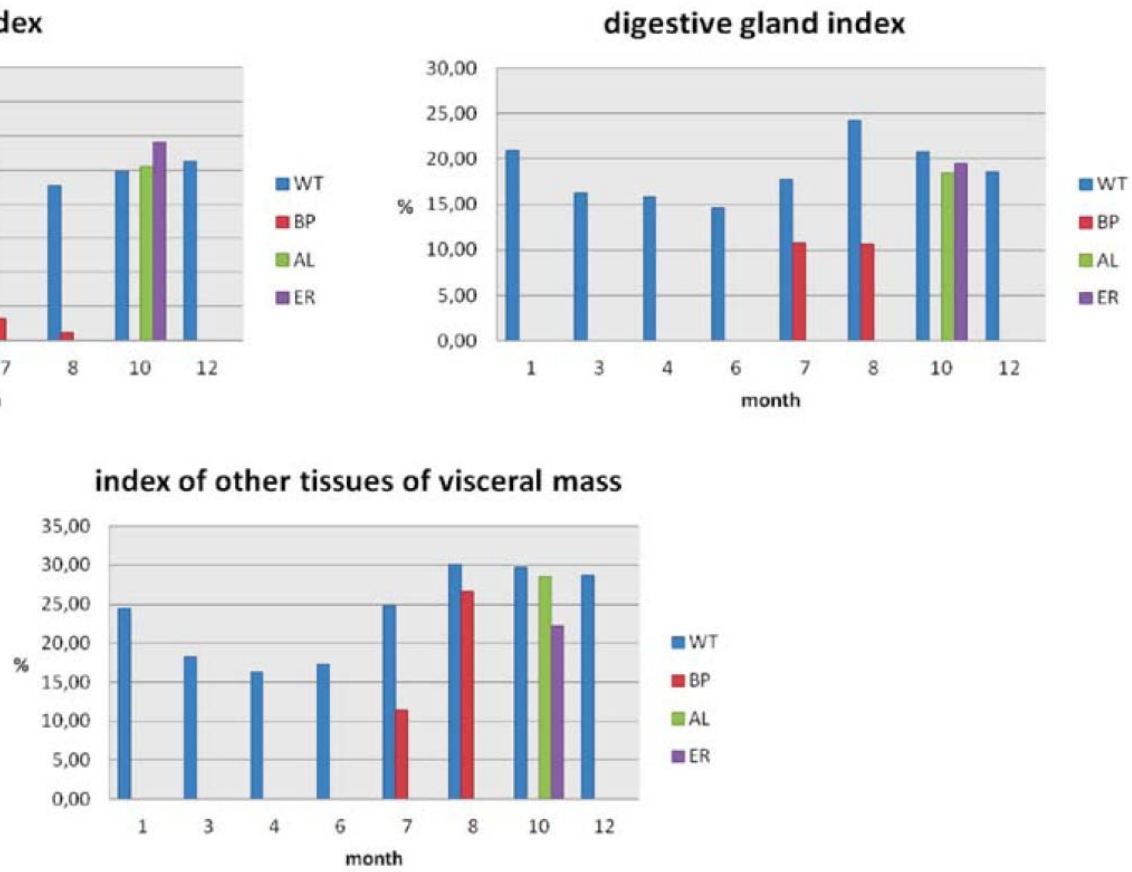

Fig. 4. Comparison of indexes of infected and uninfected Dreissena polymorpha during one year.

WT - mussels without trematodes; BP - mussel infected with Bucephalus polymorphus; AL - mussel infected with Aspidogaster limacoides; ER - mussel infected with Echinoparyphium recurvatum

The mean value of the length of the visceral mass, visceral mass volume, gonad volume and volume of other tissues of the visceral mass in healthy bivalves and in bivalves infected with trematodes is shown in Table 2. An analysis of the
Aspidogaster limacoides (Aspidogastrea: Aspidogastridae) A trematode was found in the stomach cavity in a male bivalve sampled in October (Fig. 3). The ventral and dorsal side were clearly distinguishable in the trematode. A large 
ventral disc with longitudinal rows of alveoli was visible on the ventral side, which is a characteristic of the Aspidogastridae family. The bivalve gonads were in a dormant state.

The volume analysis indicated that a significant reduction of tissue occurred in the bivalve (Table 2). The values of all measured volumes were up to $45 \%$ less than those in uninfected bivalves. The values of the indices were not statistically significant between infected and uninfected animals (Fig. 4).

\section{Discussion}

According to the literature data, the prevalence of trematode infection of species $D$. polymorpha can vary widely. The species $B$. polymorphus causes the greatest infection. In the Seine River in France, an infection prevalence of greater than $73 \%$ has been recorded (Wallet and Lambert, 1986), though significantly lower values have also been reported, i.e. 1\% (Kuperman et al., 1994), $9 \%$ (Molloy et al., 1996), 13 - $28 \%$ (de Kinkelin et al., 1968), and $21.3 \%$ (Lajtner et al., 2008). The species E. recurvatum causes a much lower rate of infection, ranging from $<1 \%$ (Molloy et al., 1997) to $8.5 \%$ (Kochnev, 1977). For the genus $A s-$ pidogaster these values are even lower, ranging from $0.1 \%$ (Nagibina and Timofeeva, 1971), <1 \% (Molloy et al., 1996) to $3.8 \%$ (Kuperman et al., 1994).

An analysis of the bivalves infected with the species $B$. polymorphus indicated that the gonads are most afflicted by infection, which is also a characteristic of this trematode species (Laruelle et al., 2002; Lajtner et al., 2008; Minguez et al., 2012). As the infection advances, the sporocysts spread into the other organs, including the digestive glands, kidneys, pericardial cavity, dorsal part of the gills, mantle and the adductor muscles. These organs are also known as the organs afflicted by secondary infections (Molloy et al., 1996, 1997; Laruelle et al., 2002). The digestive gland, near to the gonads, is not infected and histologically did not differ from the remaining healthy individuals. Similar findings were reported by Molloy et al., (1996), Laruelle et al. (2002) and Lajtner et al. (2008), which further confirms the theory that the gonads are the primary organ of infection.

The sporocysts contain cercariae in varying stages of development, though these were mostly mature sporocysts. Molloy et al. (1997) stated that cercariae were released into the surrounding water over longer periods of time, which was confirmed in this study. Baturo (1978) stated that the process of releasing cercariae is positively correlated to water temperature and the higher the temperatures, the more cercariae are released (Baturo, 1978). On the other hand, the process is correlated to the development of fish fry, as this is the next intermediate host, and this development is most intensive at that time of year (Baturo, 1978; Molloy et al., 1997).

It is known that strong infections by trematodes from the Bucephalidae family lead to complete sterility of the host, and to the appearances of hermaphroditism (Tripp, 1973;
Stadnychenko, 1974; Laruelle et al., 2002). It can be assumed that the appearance of hermaphrodites in the Dubrava dam reservoir lake is associated with trematode infection. In research conducted in the Drava River, Lajtner et al. (2008) reached the same conclusions. Jokela et al. (1993) presented an interesting theory in their research of infection of the bivalve Anodonta piscinalis by the trematode Rhipidocotyle fennica. They concluded that trematodes from this family have a specific parasitic strategy, as they use only the reproductive energy of their host, thus minimizing the risk of death. The continued life of their host is important for the trematode, as the infection is passed on from year to year, in which the infected gonads produce cercariae instead of gametes (Taskinen et al., 1994). Considering that the gonads of the bivalves from the Dubrava dam reservoir lake were not afflicted, it can be assumed that this infection is not lethal for bivalves and can potentially be transferred into the following year.

Unlike the species from the Bucephalidae family, trematodes from the Echinostomatidae family using bivalves as secondary intermediate hosts. In other words, the already developed cercariae enter into the bivalve where they transform into metacercariae. Three species from the Echinostomatidae family have been found as parasites in the bivalve D. polymorpha: E. recurvatum, E. echinatoides and E. paraulum (Molloy et al., 1997).

The analysis of bivalves from the Drava River shows that only one bivalve was infected with metacercariae of the trematode E. recurvatum. This was a male sampled in October. Though determination of the species is quite difficult on histological preparations, the diameter of the metacercariae of 148.5 and $164.8 \mu \mathrm{m}$ corresponds to the species E. recurvatum (120 to $165 \mu \mathrm{m}$ diameter) (Yamaguti, 1975; Laruelle et al., 2002). Furthermore, the double wall of the cyst and thin layer of host connective tissue around the cyst also suggest this is the species E. recurvatum. Only two cysts with metacercariae were found in the bivalve. One was situated in the outer epithelium of the visceral mass, and the second in the connective tissue between the gonads and digestive glands. Conn and Conn (1995) reported finding cysts of E. recurvatum in the gonads of $D$. polymorpha experimentally infected with these trematodes. Laruelle et al. (2002) were the first to find cysts of these trematodes in bivalves in situ. The site of infection observed in this paper is similar to that of other intermediate hosts: mantle epithelium, connective tissue of the visceral mass and, to a lesser extent, the kidneys, haemolymphatic sinuses, pericardial cavity, suprabranchial cavity, digestive lumen and gonads (Anderson and Fried, 1987; Adam and Lewis, 1992).

The effect of the species E. recurvatum on D. polymorpha appears to be benign, which is a characteristic of infection by trematodes from the Echinostomatidae family (Laruelle et al., 2002). Visible signs of infection include the accumulation of haemocytes at the infection site, without haemocytic encapsulation. Bower et al. (1994) reached a similar conclusion in their study of the infection of marine bivalves with trematodes of the Echinostomatidae family. 
According to these authors, infections by trematodes from this family are not pathogenic, but can cause compression of the surrounding tissue, reduce byssus production and induce the formation of pearl structures.

To date, two species of the Aspidogastridae family have been reported to parasitize the bivalve $D$. polymorpha: Aspidogaster conchicola and A. limacoides (Molloy et al., 1997). Unlike trematodes from the genus Digenea, these trematodes complete their life cycle in a single host (Rohde, 1972). Adult worms produce eggs in which a nonciliated larva with an anterior and posterior sucker develops. There are conflicting reports on how molluscs become infected: either by eggs containing larvae or by hatched larvae. The life cycle can be repeated without involvement of a vertebrate host, but if a fish eats an infected mollusc, adults can produce eggs within. Aspidobothreans are able to either self-fertilize or mate with another individual (Bakker \& Davids, 1973; Huehner \& Etges, 1977).

A. conchicola is typically positioned in the pericardial and renal cavities (Bakker and Davids, 1973). Kuperman et al. (1994) found A. limacoides in the gonads and pericardial cavity, while Molloy et al. (1996) found it attached to the ventral surface of the visceral mass and inside the gonads of D. polymorpha. Laruelle et al. (2002) confirmed the presence of these trematodes in the digestive glands and in the stomach of $D$. polymorpha. In the present study, trematodes were found in bivalves sampled in October. The bivalve gonads were in a dormant state, and so it is not possible to determine the effect of the trematode $A$. limacoides on the gonads. Molloy et al. (1996) reported that the presence of these aspidogastrids caused no obvious adverse effects on the dreissenids; infected male and female mussels were sexually mature.

It is known that $A$. conchicola feeds on blood cells and haemolymph (Gentner, 1971). Huehner et al. (1989) established that this species uses its strong ventral suckers to feed on the blood of the host, the mollusc Anodonta grandis, feeding also on its epithelial cells. Laruelle et al. (2002) stated that it is not known exactly which cells are eaten by the trematodes infecting $D$. polymorpha. However, the authors observed haemocytic bleeding at the infection sites and assumed that the haemocytes are certainly a target food. It can be assumed that if bivalves from the Drava River are infected with these trematodes this will result in their death.

\section{Acknowledgements}

This study was supported by the Ministry of Science, Education and Sports of the Republic Croatia (project No. $0119125)$. I am very grateful to anonymous reviewers for helpful comments on the manuscript.

\section{References}

ADAM, M. E., LEWIS, J. W. 1992. Sites of encystment by the metacercariae of Echinoparyphium recurvatum in Lymnaea peregra. J. Helminth., 66: 96 - 99. DOI: 10.10

\section{7/S0022149X00012657}

ANDERSON, J. W., FRIED, B. 1987. Experimental infection of Physa heterostropha, Helisoma trivolvis, and Biomphalaria glabrata (Gastropoda) with Echinostoma revolutum (Trematoda) cercariae. J. Parasitol., 73: 49 - 54

BAKKER, K. E., DAVIDS, C. (1973): Notes on the life history of Aspidogaster conchicola Baer, 1826 (Trematoda: Aspidogastridae). J. Helminth., 47: 269 - 276

BATURO, B. (1978): Larval bucephalosis in artificially heated lakes of the Konin region, Poland. Acta Parasitol., 25: $307-321$

BORCHERDING, J. (1991): The annual reproductive cycle of the freshwater mussel Dreissena polymorpha Pallas in lakes. Oecologia, 87: 208 - 218. DOI: 10.1007/BF00325258 Bower S. M., MCGladdery S. E., PrICE I. M. (1994): Synopsis of infectious diseases and parasites of commercially exploited shellfish. Ann. Rev. Fish Dis., 4: 1 - 199. DOI: 10.1016/0959-8030(94)90028-0

Burlakova L. E., Karatayev A. Y., Padilla D. K. (2000): The impact of Dreissena polymorpha (Pallas) invasion on unionid bivalves. Int. Rev. Hydrobiol., 85: 529 - 541. DOI: 10.1002/1522-2632(200011)85:5/6<529::AID -IROH529>3.0.CO;2-O

ConN, D. B., ConN, D. A. (1995): Experimental infection of zebra mussels Dreissena polymorpha (Mollusca: Bivalvia) by metacercariae of Echinoparyphium sp. (Platyhelminthes: Trematoda). J. Parasitol., 81: $304-305$

DE Kinkelin, P., TUfFERY, G., LeYNAUd, G., ARRIGNON, J. (1968): Étude épizootiologique de la Bucéphalose larvaire a Bucephalus polymorphus (Baer 1827) dans le peuplement piscicole du bassin de la Seine. Rech. Vét. , 1: $77-98$ ERBEN R., LAJTNER J., LUCiĆ A., MAGUIRE I., KLOBUČAR G. I. V. (2000): Attachment of the zebra mussel on the artificial substrates in the reservoir Dubrava (River Drava, Croatia). Limnol. Rep., 33: 225 - 231

ERBEN, R., LuCiĆ, A., TARNIK, T., LAJTNER, J., BUHIN, J. (2009): Seasonal distribution of the zebra mussel (Dreissena polymorpha, Pallas) larvae in the dam reservoirs Dubrava, Varaždin and Čakovec, Croatia. Verh. Internat. Verein. Limnol., 30: $714-716$

Gentner, H. W. (1971): Notes on the biology of Aspidogaster conchicola and Cotylaspis insignis. Zeit. Parasit., 35: $263-269$

Hebert, P. D. N., Muncaster, B. W., Mackie, G. L. (1989): Ecological and genetic studies on Dreissena polymorpha (Pallas): a new mollusc in the Great Lakes. Can. J. Fish. Aquat. Sci., 46: $1587-1591$

Huehner, M. K., Hannan, K., Garvin, M. (1989): Feeding habits and marginal organ histochemistry of Aspidogaster conchicola (Trematoda: Aspidogastrea). J. Parasitol., 75: $848-852$

HueHner, M., EtGes, F. (1977): The life cycle and development of Aspidogaster conchicola in the snails, Viviparus malleatus and Goniobasis livescens. J. Parasitol., 63: $669-674$

JOKELA, J., UOTILA, L., TASKINEN, J. (1993): Effects of the castrating trematode parasite Rhipidocotyle fennica on energy allocation of fresh-water clam Anodonta piscinalis. 
Funct. Ecol., 7: $332-338$

Karatayev A. Y., Burlakova L. E., Molloy D. P., VolKOVA L. K. (2000): Endosymbionts of Dreissena polymorpha (Pallas) in Belarus. Int. Rev. Hydrobiol., 85: $539-555$

KOCHNEV, S. A. (1977): Infection with trematode metacercariae of Dreissena polymorpha in a reservoir warmed by waters of the thermo-electric station. Ekol. Gel. 5: 46-52 Kuperman, B. I., ZhOCHOV, A. E., PopOva, L. B. (1994): Parasites of Dreissena polymorpha (Pallas) molluscs of the Volga basin. Parazitologiya (Leningrad), 28: 396 - 402

LAJTNER, J., MARUŠIĆ, Z., KlOBUČAR, G. I. V., MAGUIRE, I., ERBEN, R. (2004). Comparative shell morphology of the zebra mussel, Dreissena polymorpha in the Drava river (Croatia). Biologia (Bratislava), 59: 595 - 600

LAJTNER, J., LuCiĆ, A., MARUŠić, M., ERBEN, R. (2008): The effects of the trematode Bucephalus polymorphus on the reproductive cycle of the zebra mussel Dreissena polymorpha in the Drava River. Acta Parasitol 53: 85 - 92. DOI: $10.2478 / \mathrm{s} 11686-008-0011-1$

Laruelle, F, Molloy, D. P., Roitman, V. A. (2002): Histological analysis of trematodes in Dreissena polymorpha: their location, pathogenicity, and distinguishing morphological characteristics. J. Parasitol., 88: 856 - 863. DOI: 10.1645/0022-3395(2002)088[0856:HAOTID]2.0CO;2

MingueZ, L, Buronfosse, T., Giambérini, L. (2012): Different host exploitation strategies in two zebra musseltrematode systems: Adjustments of host life history traits. PLoS ONE 7: e34029. DOI:10.1371/journal.pone.0034029 Molloy, D. P., Roitman, V. A., Shields, J. D. (1996): Survey of the parasites of zebra mussels (Bivalvia: Dreissenidae) in northwestern Russia, with comments on records of parasitism in Europe and North America. $J$. Helminth. Soc. Wash., 63: $251-256$

Molloy, D. P., Karatayev, A. Y., Burlakova, L. E., KuRANDINA, D. P., LARUElLE, F. (1997): Natural enemies of zebra mussels: predators, parasites, and ecological competitors. Rev. Fish. Sci., 5: 27 - 97. DOI: 10.1080/ 10641269709388593
MORTON, B. S. (1969): Studies on the biology of Dreissena polymorpha Pall. I. General anatomy and morphology. Proc. Malacol. Soc. London, 38: 301 - 321

NAgiBinA, L. F., TimofeEva, T. A. (1971): True hosts of Aspidogaster limacoides Diesing, 1834 (Trematoda, Aspidogastrea). Dokl. Akad. Nauk SSSR 200: 677 - 678

PERIBÁÑEZ, M. A., Elrío, M. L., Gracia, M. J., DE LuCO, D. F., Castillo, J. A., Lucientes, J., Cia I. (2006): Phyllodistomum folium (Trematoda: Gorgoderidae) infecting zebra mussels (Dreissena polymorpha) in the Ebro River, Spain, Parasitol. Int., 55: $143-145$. DOI: 10.1016/j.parint.2005.12.002

RoHDE, K. (1972): The Aspidogastrea, especially Multicotyle purvisi Dawes, 1941. Adv. Parasitol., 10: 77 - 151

ROMEIS, B. (1968): Mikroskopische technik. 16 Aufl Oldenbourg, München, 695 pp.

STADNYCHENKO, A. P. (1974): The infection of Unio pictorum and Anodonta piscinalis (Mollusca, Lamelibranchia) with parthenites of Bucephalus polymorphus Baer (Trematodes) and the effect of the parasites on the host's organism. Parazitologiya (Leningrad), 8: 420 - 425

STANCZYKOWSKA, A. (1977): Ecology of Dreissena polymorpha (Pall.) (Bivalvia) in lakes. Pol. Arch. Hydrobiol., 24: $461-530$

TAskinen, J., VAltonen, E. T., Makela, T. (1994): Quantity of sporocysts and seasonality of two Rhipidocotyle species (Digenea: Bucephalidae) in Anodonta piscinalis (Mollusca: Bivalvia). Int. J. Parasitol., 24: 877 886. DOI: 10.1016/0020-7519(94)90014-0

TRIPP, M. R. (1973): Hermaphroditism in Bucephalus-infected oysters. J. Inv. Path., 21: 321 - 322. DOI: 10.1016/ 0022-2011(73)90221-8

WAllet, M., LAMBERT, A. (1986): Enquête sur la répartition et l'evolution du parasitisme a Bucephalus polymorphus Baer, 1827 chez le mollusque Dreissena polymorpha dans le sud-est de la France. Bull. Fr. Pêche Piscic., 300: $19-24$

YAMAGUTI, S. (1975): A synoptical review of life histories of digenetic trematodes of vertebrates. Keikagu Publishing Company, Tokyo, p 590. 